\title{
PERGESERAN PARADIGMA KEAGAMAAN MAHASISWA MUSLIM DI UNIVERSITAS WIDYAGAMA MAHAKAM SAMARINDA
}

\author{
The Shifting of the Religious Understandings of Muslim Students \\ at Universitas Widyagama Mahakam Samarinda
}

\author{
Shadiq Kawu \\ Balai Penelitian dan Pengembangan Agama Makassar \\ Jl. AP. Pettarani No. 72 Makassar \\ Email: shaqidkawu@yahoo.com
}

Naskah diterima tanggal 24 Agustus 2015. Naskah direvisi tanggal 07 Oktober 2015. Naskah disetujui tanggal 03 November 2015.

\begin{abstract}
Abstrak
Penelitian ini berupaya mengidentifikasi pergeseran paham keagamaan yang terjadi dikalangan mahasiswa sekaligus memahami bagaimana pergeseran itu terjadi. Penelitian menggunakan metode kualitatif dan penggalian data dilakukan dengan cara wawancara terhadap tokoh-tokoh yang dipilih (purposive sampling). Hasil penelitian menunjukkan bahwa pergeseran paham yang terjadi di kalangan mahasiswa muslim di UWGM Samarinda adalah pergeseran paham keagamaan ke arah paham keagamaan yang revivalis-modernis. Pergeseran pemahaman keagamaan tersebut disebabkan oleh kuatnya penetrasi kelompok tarbiyah Ikhwanul Muslimin hingga akhirnya berhasil menguasai Lembaga Dakwah Kampus yang memiliki saluran resmi dari kampus. Dalam konteks kehidupan dewasa ini paham keagamaan yang diusung sangat resisten karena bersikap anti terhadap berbagai khasanah tradisi Islam lokal termasuk juga sikap yang cenderung intoleran terhadap kelompok Islam yang tidak sehaluan dengan mereka.
\end{abstract}

Kata kunci: pergeseran, paham, keagamaan, mahasiswa muslim

\begin{abstract}
This study attempted to identify the shift in the religious paradigm occurred among the university students and to know how the shift took place. The research employed qualitative method, and the data were obtained through the interviews of particular figures chosen purposively. The results showed that the shift of understanding occurred among the Muslim students at UWGM Samarinda is revivalist-modernist. The shift was caused by the strong penetration of education groups of Ikhwanul Muslimin which finally dominated the Islamic campus organizations which were under umbrella of campus. In the context of life nowadays, the understandings promoted are highly resistant because of being anti to various Islamic repertoires of local traditions, and also tended to be intolerant towards other Islamic groups especially those who were not in line with them.
\end{abstract}

Keywords: shift, understanding, religious, Muslim students

\section{PENDAHULUAN}

$\mathrm{P}$ roses globalisasi telah berhasil mengaburkan sekat antara negara, dunia menjadi global village yang di mana antara satu wilayah dengan wilayah lain dapat saling mengakses satu sama lain dalam waktu seketika. Dengan retasnya ruang tersebut berimplikasi pada pergerakan paham dan ideologi dari satu negara ke negara lain. Key Deaux dan Shaun Wiley dalam Gail Moloney 
(2007), pernah menyebut adanya moving people dan shifting representation dalam konteks globalisasi ini. Di mana terjadi pergerakan sekolompok orang dari negara atau tempat tertentu ke tempat yang lain. Ini akan mengakibatkan perubahan populasi dalam satu tempat yang pada akhirnya menggeser orangorang dalam merepresentasikan paham keagamaan mereka. Bahkan lebih dari itu, Woodward (2007) menyatakan movingpeople and shifting representation ini, bukan sekedar pergerakan sekolompok orang tapi juga bergerak atau masuknya paham atau ideologi baru ke negara tertentu, khususnya paham keagamaan. Pergerakan ideologi global ini melintas tanpa basis-basis kebangsaan, juga tidak mengenal konsep nation state. Pergerakannya melintasi batasbatas negara bangsa. Acap kali gerakan ini juga berupaya mempengaruhi kebijakan politik dalam suatu Negara, tujuannya bukan untuk kepentingan bangsa ini sendiri tapi justru untuk kepentingan global. Pada ranah kebangsaan misalnya, ada upaya untuk mendesakkan Indonesia didasarkan pada paham keagamaan tertentu. Muncul tuntutan untuk merubah konstitusi Negara Pancasila dan UUD 1945.

Arus penyebaran paham dari satu negara ke negara lain juga menyangkut paham keagamaan yang ditransformasi masuk kepada kelompokkelompok tertentu dari satu negara ke negara yang lain. Kelompok yang paling rentan sebagai sasaran "missionari" paham keagamaan baru tersebut adalah kelompok muda terdidik yang memiliki kesempatan dan akses pada perkembangan wacana pemikiran dan ideologi dari berbagai belahan dunia, dalam hal ini adalah kalangan mahasiswa. Paham keagamaan Islam akhirnya muncul beraneka rupa, Abudin Nata (2001: 6) menyebutkan munculnya beberapa corak paham keislaman, yaitu fundamentalis, normatifteologis, eksklusif, rasional, pluralis-inklusif, transformatif, aktual, kontekstual, kultural, politis, dinamis-modernis, liberal, dan lain sebagainya.

Para mahasiswa digodok sedemikian rupa dalam pengkaderan dan diskusi rutin. Mereka di jejali bacaan-bacaan; baik berupa bulletin maupun buku-buku, yang menampilkan pemahaman agama yang berbeda dengan yang dipahaminya selama ini. Mereka pada akhirnya memahami agama lain dari yang menjadi mainstream pemahaman Islam dari mahasiswa selama ini. Dulu di kalangan mahasiswa yang berkembang adalah paham-paham keagamaan Islam Ahlusunnah wal jamaah yang dikembangkan
NU dan Muhammadiyah. Paham keagamaan tersebut direpresentasikan oleh organisasi semacam PMII, HMI dan IMM. Pemahaman agama semacam ini nampak dalam sikap keagamaan mahasiswa yang toleran dan menghargai khazanah keislaman, mengapresiasi tradisi dan juga rasa cinta terhadap tanah air.

Sekarang yang marak adalah munculnya organisasi keislaman di mana representasi keagamaan mereka jauh merujuk keluar negeri, melintas batas negara. Inilah yang menimbulkan munculnya paham-paham keagamaan baru di kalangan mahasiswa muslim. Mereka merepresentasikan diri dalam Lembaga Dakwah Kampus, Halaqah dengan berbagai nama, dan Komite-komite Aksi Mahasiswa. Mereka juga muncul dalam bentuk diskusi dan kajian jumatan yang rutin dengan mengangkat issu-issu keagamaan yang lebih radikal dan ekstrim.

Hal ini misalnya tercermin dari penelitian Litbang Agama Makassar pada tahun 2010 tentang paham keagamaan mahasiswa, disitu tergambar bagaimana mahasiswa lebih dari $60 \%$ setuju mendorong adanya penerapan syariat Islam atau formalisasi agama (Penelitian Litbang Paham Keagamaan Mahasiswa, 2010). Tidak berhenti sampai disitu saja, banyak kalangan mahasiswa mulai kehilangan kebanggaan terhadap Pancasila dan bentuk negara Indonesia sekarang ini. Mereka mulai mengusung munculnya negara khilafah Islamiyah. Ini menunjukkan tujuan yang mereka perjuangkan bukan lagi tanah air tapi sesuatu yang bersifat transnasional.

Cerminan dari pergeseran representasi keagamaan ini nampak pula dalam berbagai aktivitas beberapa kalangan mahasiswa. Mereka dalam berdiskusi sering mengangkat isu-isu soal khilafah Islamiyah. Hal ini bahkan ditindaklanjuti dalam bentuk aksi-aksi turun ke jalan menuntut perubahan dasar dan bentuk negara. Sementara itu di sisi yang berbeda sebagai antitesa dari gerakan fundamentalis-radikal ini, muncul pula mahasiswa dengan kecenderungan paham yang lebih liberal. Kelompok ini justru menjakiti kelompok PMII, HMI dan IMM yang dulunya mengusung Islam yang khas Nusantara. Muncullah kelompok semacam Jaringan Mahasiswa Moderat (JMM) yang sebelumnya dilatih oleh kelompok LSM tertentu yang liberal. Juga muncul kelompok JIMM (Jaringan Islam Muda Muhammadiyah). Kelompok ini lebih toleran dan 
terbuka, namun basis paham keagamaannya juga bergeser dari Islam khas Nusantara ke paham yang lebih liberal.

Pergeseran paham keagamaan di kalangan mahasiswa ini, bisa mengganggu kualitas kehidupan keagamaan yang dicanangkan Negara. Pertama; hal ini ini bisa memicu sikap intoleransi bahkan kekerasan yang berbasis agama. Sikap ini lebih jauh akan mengganggu jaminan menjalankan agama bagi seluruh agama di Indonesia sebagaimana dijamin pasal 29 UUD 1945. Kedua; bergesernya paham keagamaan Islam mejadi ekstrem fundamentalis dan liberal di kalangan mahasiswa bisa menghilangkan rasa cinta terhadap nilai kebangsaan dan keagamaan khas Nusantara yang menjadi ciri kita selama ini.

Adapun permasalahan dari penelitian ini adalah: bagaimana bentuk-bentuk pergeseran paham keagamaan di kalangan mahasiswa baik dari segi pemikiran maupun gerakan di Universitas Widyagama Mahakam Samarinda? Dan bagaimana dampak perubahan keagamaan mahasiswa ini dalam kehidupan beragama dan berbangsa di Indonesia di kalangan mahasiswa Universitas Widyagama Mahakam Samarinda?

\section{Tinjauan Pustaka}

\section{Pergeseran Paham Keagamaan}

Dalam konteks globalisasi saat ini, sekatsekat negara menjadi semakin kabur. Hal ini memudahkan paham ekonomi, politik, teori, idiologi, teknologi dan juga berbagai paham negaranegara di dunia saling melintas batas. Globalisasi tak pelak lagi melahirkan satu model berbangsa, bernegara, berideologi bahkan beragama yang tidak lagi tunggal, namun semakin beragam.

Globalisasi juga mendorong kosmopolitanisme. Namun, di saat yang sama ada penguatan identitas yang mendasarkan dirinya pada komunalitas dan institusi sosial tradisional. Maka, jika globalisasi menawarkan berbagai paham baru yang diproduksi dari luar, di masyarakat satu bangsa sendiri mencoba mencari-cari representasi dirinya pada sesuatu yang bersifat lokal. Inilah yang disebut Ulrich Beck sebagi kontradiksi globalisasi. Hal ini memang mengakibatkan adanya pergeseran masyarakat dalam merepresentasikan diri namun sejauh hal ini bisa dikelola, maka yang dilahirkan biasanya hal yang positif. Di sini muncul konsep kewargaan baru yang mengakomodasi lokalitas. Misalnya dalam agama berkembang kembali agama dengan warna lokalitasnya.
Hanya saja akhir-akhir ini seperti yang dikemukakan oleh Key Deaux dan Shaun Wiley dalam Gail Moloney (2007) pergerakan sekolompok orang dari satu negara ke negara lain, lebih massif. Hal ini menurut Woodward (2007) secara sistematis mengubah paham-paham dalam negara tertentu karena memang ada aktor yang membawa agenda tersebut. Apalagi proses ini diperkuat dengan teknologi informasi yang semakin hebat. Di Indonesia hal ini sangat terasa dalam konteks paham keagamaan. Di mana saat ini di Indonesia dengan sangat mudah berbagai paham-paham keagamaan masuk dan mempengaruhi masyarakat Indonesia. Paham-paham keagamaan tersebut, khususnya jika kita amati pada masyarakat Islam, telah menumbuhkan lahirnya berbagai aliran baru.

Pergeseran paham keaagamaan dalam konteks ini lebih cenderung dilihat sebagai sebuah proses yang disengaja dan secara sistematis dilakukan oleh kalangan tertentu. Tujuannya memang untuk mengubah paham keagamaan masyarakat (dalam hal ini mahasiswa). Tujuan yang ingin dicapai bukan untuk kepentingan bangsa dan tanah air kita, tapi lebih kepada agenda kelompok tertentu yang biasanya justru ada di Negara lain. Pergeseran ini titik tekannya bukan dalam konteks pertemuan atau dialog konstrukstif antara yang global dan lokal yang melahirkan glokalisasi, namun murni sebagai sebuah infiltrasi organisasi dan kelompok tertentu di Indonesia untuk merubah paham keagamaan kita. Karena itu pergeseran paham keagamaan semacam ini biasanya tidak memberi tempat pada tradisi Nusantara dan juga kurang menghargai pendapat ulama-ulama dulu dari Nusantara ini.

\section{Fundamentalisme-Radikalisme}

Istilah fundamentalisme sebenarnya problematik untuk digunakan. Hal ini karena fundamentalisme bisa berarti beragama secara mendasar dan mendalam. Dalam konteks ini semua penganut agama membutuhkan sikap tersebut. Beberapa tokoh memakai istilah lain untuk menggantikan kata fundamentalisme ini. Khaled Aboe al-Fadl (al-Fadl, 2005), lebih senang menggunakan kata puritanisme, untuk menunjuk kelompok Islam yang dianggap memiliki pandangan absolutisme dan tanpa kompromi. Beberapa pemikir lainnya menggunakan istilah berbeda. Gilles Kivel dan Emmanuel Sivan menggunakan istilah 'Islam radikal' (Sivan, 1990). Adapula yang menggunakan 
istilah integrisme, revivalisme dan islamisme untuk menilai gerakan keagamaan.

Jika ditelusuri, kata-kata fundamentalisme ini muncul pertama kalinya dalam The Shorter Oxford English Dictionary pada 1923. Istilah yang muncul pada awal abad ke-20 ini sebagai kerangka kerja kaum Protestan konservatif di Amerika, untuk menunjukkan ciri doktrin yang berdasarkan kitab injil (Rumadi, 2009). Ada lima poin yang menjadi pandangan kaum Protestan konservatif tersebut, yaitu kelahiran Yesus dari sang perawan, kebangkitan fisiknya, kitab Injil yang tanpa salah, penebusan dosa dan kedatangan Kristus yang kedua. (Riffat Hassan, 1993). Bila hal ini kemudian disematkan ke Islam, maka hanya satu bagian dari kelima poin itu yang mungkin sama, yaitu soal kitab Injil dalam Islam tentunya Alquran yang tak pernah salah.

Penelitian ini mencoba melihat pergeseran ke arah fundamentalisme Islam ini dengan menggunakan pola E. Marty ini. Namun dengan beberapa perubahan dan tambahan. Dalam penelitian ini kita sebut saja dengan fundamentalisme-radikalisme. Ciri-cirinya sebagai berikut: Pertama, cara memhamai teks keagamaan yang tekstual dan memonopoli tafsir agama. Kedua, intoleran terhadap yang berbeda. Karenanya mereka bisa melakukan tindakan kekerasan atau menyetujui tindakan tersebut. Ketiga, menolak modernitas, khususnya konsep-konsep yang terkait dengan penghargaan keragaman. Keempat, mereka melakukan gerakan politik kekuasaan. Kelima, tidak meyakini konsep Negara Kesatuan Republik Indonesia dan Pancasila sebagai dasar Negara.

\section{Liberalisme}

Islam liberal menjadi wacana yang meramaikan khazanah intelektual Islam dengan buku Greg Barton Gagasan Islam Liberal di Indonesia (1999) dan juga buku Charles Kurzman Liberal Islam (1998). Dalam pandangan dua orang ini liberalism Islam adalah paham yang membuka wacana ijtihad dan kebebasan berpikir dalam Islam (Ahmad Baso, 2012). Namun dalam dua pandangan pemikir ini, konsep liberalisme hanya dilihat dari berbagai gagasan yang terpisah-pisah dari berbagi tokoh di Indonesia seperti Gusdur misalnya dengan melihat gagasan sekularismenya.

Apa yang dimaksud dengan Islam liberal oleh Greg dan Kurzman, sebelumnya juga telah dikemukakan oleh Leonard Binder (Binder, 1988). Namun penekanan liberal oleh tokoh ini adalah adanya dialog antara Islam dan Barat. Pada titik itu ada proses saling menimba ilmu dan dialog kritis antara keduanya.

Greg Barton dan kurzman justru menekankan liberalisme itu lebih mirip dengan pemurnian Islam dengan mencari-cari liberalisme itu pada ajaran murni Islam, yaitu pada Alquran dan Hadist.

Pola-pola Islam liberalisme dapat dilihat mulai dari :

- Cara berfikir yang sangat terbuka, menghargai kebebasan.

- Membuka ijtihad selebar-lebarnya.

- Tidak berbasis pada khazanah intelektual Islam klasik dalam membangun dialog dengan tradisi intelektual Barat.

- Tidak meyakini kekuatan ide dan metodologi ulama-ulama Nusantara.

- Tidak memberikan tempat pada khazanah dan tradisi Nusantara dalam praktek keberIslaman. (ziarah kubur dan selamatan dianggap kejumudan).

\section{METODE PENELITIAN}

Penelitian menggunakan metode kualitatif. Metode ini dilakukan di lapangan untuk menggali data-data dengan cara melakukan wawancara terhadap tokoh-tokoh yang dipilih (purposive sampling). Tokoh-tokoh ini dianggap merepresentasikan topik penelitian. Ada dua bentuk informan dalam konteks ini; pertama yaitu yang memahami persoalan pergeseran paham keagamaan; mereka bisa intelektual, akademisi, dan tokoh mahasiswa. Kedua kelompok yang dianggap bagian dari yang paham keagamaannya telah mengalami pergeseran, yang ini dari kalangan mahasiswa khususnya yang aktif dalam organisasi keislaman tertentu.

Karena penelitian ini berupaya mengidentifikasi pergeseran paham keagamaan tersebut sekaligus memahami bagaimana pergeseran itu terjadi, maka teknik wawancara lebih mengandalkan wawancara tak terstruktur. Meski untuk identifikasi itu sendiri akan dibantu dengan pertanyan terstruktur. Untuk wawancara tak terstruktur Pada peneliti hanya akan diberikan guide interview sekedar sebagai panduan umum dan pertanyaan reflektif peneliti sendiri pada dirinya. Dalam proses ini peneliti dituntut untuk 
mengembangkan sendiri wawancaranya secara mendalam. Sementara yang wawancara terstruktur akan dipandu dengan pertanyaan-pertanyaan tertentu.

\section{PEMBAHASAN}

\section{Profil Universitas Widyagama Mahakam Samarinda \\ Sejarah Berdiri}

Universitas Widyagama Mahakam adalah salah satu kampus swasta terbesar di Samarinda yang berlokasi di Jalan KH. Wahid Hasyim Sempaja Samarinda. Universitas Widyagama Mahakam (Selanjutnya disebut UWGM) Samarinda didirikan pada tangga 5 Mei 1985. Sejarah pendiriannya berawal dari pertemuan yang tidak terduga di Sarinah Malang pada Juni 1984, seorang rekan menyampaikan gagasan mendirikan Universitas di Samarinda kepada Drs. Ismet Barakbah, dengan latar belakang pemikiran bahwa puteraputeri Kalimantan Timur yang menuntut ilmu di Universitas Widya Gama Malang jumlahnya lebih dari 100 (seratus) orang dan ini berarti akan lebih banyak lagi lulusan SLTA dari Kalimantan Timur yang berkeinginan melanjutkan studi ke perguruan tinggi, baik dalam wilayah Kalimantan Timur maupun ke luar daerah (pulau Jawa, Ujung Pandang, Banjarmasin, dan lain-lain).

Gagasan yang masih mentah tersebut oleh Drs. Ismet Barakbah, disampaikan kepada Drs. Ramli Yahya yang pada waktu itu banyak memberikan input kepada Bapak H. Suwandi (Alm.) selaku Gubernur Kepala Daerah Tingkat I Provinsi Kalimantan Timur yang juga menjabat sebagai pada Ketua Yayasan pengasuh Universitas Widyagama Malang turut menyambut baik gagasan tersebut, namun beliau tidak menginginkan kehadiran Perguruan Tinggi Swasta (PTS) baru justru menghambat perkembangan PTS yang telah ada, khususnya dalam hal kemungkinan kelebihan daya tampung terhadap lulusan SLTA se-Kalimantan Timur.

\section{Visi dan Misi}

Visi dari UWGM Samarinda adalah Menciptakan Sumber Daya Manusia yang handal, berkualitas, menguasai Ilmu Pengetahuan dan Teknologi, beriman, bertaqwa kepada Tuhan Yang Maha Esa, berbudi pekerti luhur, berkepribadian yang mantap dan mandiri serta berorientasi masa depan. Sedangkan Misi dari kampus UWGM adalah:

a. Menyelenggarakan pendidikan yang mendukung pembangunan bangsa dengan mengedepankan pembinaan suasana akademik yang sehat, demokrasi, keterpaduan kegiatan kurikuler dan ekstra kurikuler memanfaatkan teknologi dan informasi yang mutakhir dengan memperhatikan perkembangan budaya masyarakat.

b. Menyelenggarakan pendidikan untuk menghantarkan peserta didik menjadi manusia yang berkualitas, bertaqwa kepada Tuhan Yang Maha Esa, memiliki rasa kebangsaan, berjiwa entrepreneur, berkemampuan akademik dan /atau professional hingga mampu berperan secara bermakna disegala aspek kehidupan masyarakat.

c. Mengembangkan ilmu pengetahuan dan teknologi untuk kesejahteraan masyarakat berlandaskan keimanan dan taqwa kepada Tuhan Yang Maha Esa sesuai dengan Pancasila dan UUD Negara Republik Indonesia.

\section{Fakultas dan Program Studi}

Terdapat 6 fakultas dan 10 prgram studi yang dibina di kampus UWGM Samarinda. Fakultas tersebut adalah Fakultas Ekonomi yang terdiri atas 3 jurusan (Manajemen, Akuntansi, serta D-IV Keungan dan Perbankan Syariah), Fakultas Sospol dengan program studi Ilmu Administrasi Negara, Fakultas Hukum dengan program studi Ilmu Hukum, Fakultas Pertanian dengan program studi Agroteknologi, fakultas Kesehatan masyarakat dengan program studi Ilmu Kesehatan masyarakat, serta Fakultas keguruan dan Ilmu Pendidikan dengan 3 program studi (Pendidikan Bahasa Inggris, Pendidikan Guru Sekolah Dasar, dan pendidikan Anak Usia Dini). Kampus UWGM juga mengelola Program Pascasarjana (PPs) untuk program studi Ilmu Administrasi Negara dan program studi Manajemen.

\section{Dinamika Kegiatan Mahasiswa}

Dinamika kegiatan mahasiswa di UWGM diwarnai oleh kegiatan iternal maupun eksternal kemahasiswaan. Di organisasi internal kemahasiswaan setidaknya ada beberapa jenis Unit Kegiatan Mahasiswa, yang mengakomodir kecenderungan bakat dan minat mahasiswa baik di bidang kerohanin, seni, sosial, maupun olahraga. 
Kegiatan UKM tersebut memfasilitasi bakat dan minat mahasiswa pada bidang tertentu. Diantara UKM yang ada di UWGM dua diantaranya menyangkut bidang keagamaan, yaitu Centra Studi Islam Mahasiswa (CESIMA) untuk mahasiswa muslim dan Keluarga Besar mahasiswa Kristen (KBMK UWGM) untuk mahasiswa yang beragama Kristen.

Selain organisasi internal seperti UKM di UWGM juga terdapat lembaga kemahasiswaan internal, yaitu BEM (Badan Eksekutif Mahasiswa) di tingkat universitas dan fakultas serta Himpunan Mahasiswa (HIMA) di tingkat jurusan maupun program studi. Lembaga-lembaga kemahasiswaan tersebut adalah lembaga resmi mahasiswa mulai dari tingkat terrendah di program studi hingga tingkat tertinggi di universitas.

Selain dinamika kegiatan kemahasiswaan pada lembaga internal, di kampus UWGM juga terjadi dinamika kegiatan dan gerakan mahasiswa akibat pengaruh organisasi maupun kelompok eksternal kampus. Kelompok mahasiswa yang menyatakan dirinya berhaluan ideologi sosialis, nasionalis, hingga agama dengan berbagai variannya saling berdialektika satu sama lain bahkan tak jarang terjadi pergesekan, khususnya ketika berkenaan dengan momen-momen suksesi lembaga internal kampus. Banyaknya ragam kelompokkelompok kemahasiswaan dari berbagai haluan dan latar belakang di kampus UWGM, setidaknya memberikan nuansa yang berbeda dan ruang dialektika yang hidup di kampus UWGM.

Selain mendapatkan pengaruh dari dinamika organisasi internal kampus, gerakan kemahasiswaan di UWGM juga dipengaruhi oleh organisasi ekstra kampus. Terdapat beberapa organisasi ekstra kampus yang cukup aktif di UWGM. Yang paling aktif dan memiliki kader paling banyak adalah HMI (Himpunan Mahasiswa Islam) yang merupakan organisasi kemahasiswaan tertua di UWGM. Selain itu juga terdapat Kesatuan Aksi Mahasiswa Muslim Indonesia (KAMMI) serta Gerakan Mahasiswa (GEMA) Pembebasan) yang merupakan sayap organisasi dari Hizbut Tahrir Indonesia (HTI). Namun, diantara ketiga rganisasi mahasiswa Islam tersebut HMI yang paling besar jumlah kadernya. Untuk kelompok mahasiswa Kristen terdapat organisasi Gerakan Mahasiswa Kristen Indonesia. Selain organisasi kemahasiswaan berbasis agama, di UWGM juga terdapat organisasi kemahasiswaan yang berhaluan nasionalis, yaitu Gerakan Mahasiswa Nasional Indonesia (GMNI). Selain itu, di kampus UWGM juga terdapat dinamika kemahasiswaan melalui kelompok studi atau perkumpulan mahasiswa yang bersifat kultural, bukan formal sebagaimana organisasi yang tersebut di atas.

\section{Organisasi Keislaman Mahasiswa dan Peta Paham Keagamaan yang Berkembang di UWGM. Dinamika Organisasi Keislaman Mahasiswa}

Sebagaimana yang telah dijelaskan sebelumnya bahwa organisasi keislaman mahasiswa di kampus UWGM cukup beragam dan setidaknya terbagi dalam dua kategori, yaitu lembaga intra kampus dalam hal ini LDK CESIMA. Organisasi keislaman ekstra kampus pun setidaknya terbagi menjadi dua kategori, yaitu organisasi nasional, seperti HMI dan KAMMI serta organisasi kutural lokal seperti JAKFI, Gemilang, Lingkar Studi Islam, ddan lainlain. Keragaman organisasi keislaman di kampus UWGM didasarkan pada perbedaan latar belakang maupun haluan dan afiliasi ideologis masingmasing kelompok atau organisasi kemahasiswaan Islam tersebut.

Secara umum jika kita mengamati suasana kampus UWGM dinamika organisasi keislaman tidak terlihat jelas, kecuali pada momen-momen tertentu seperti pada saat suksesi HIMA Jurusan, BEM baik fakultas maupun universitas atau ketika penerimaan mahasiswa baru. Untuk organisasi eksternal kemahasiswaan yang cukup dominan adalah HMI, KAMMI, dan Gema Pembebasan. HMI sebagaimana diketahui adalah organisasi mahasiswa Islam yang paling tua dan paling heterogen. Di dalamnya terdapat banyak kelompok dan latar belakang. Berbeda misalnya dengan KAMMI maupun GEMA pembebasan yang berafiliasi pada satu corak ideologis atau gerakan Islam tertentu. KAMMI adalah organisasi kemahasiswaan Islam yang didirikan sebagai perpanjangtanganan dari kelompok Ikhwanul Muslimin atau kelompok Tarbiyah Islam, secara politik KAMMI berafiliasi pada partai Islam, yaitu PKS. Dengan demikian dapat dengan mudah dibaca arah pemikiran dan gerakan KAMMI yang lebih cenderung monotond an tidak dinamis. Sama halnya dengan organisasi GEMA Pembebasan yang merupakan sayap organisasi Hizbut Tahrir Indonesia di tingkat mahasiswa. Dengan demikian arah pemikiran dan dan gerakan GEMA Pembebasan dapat terbaca sebagai duplikasi 
pemikiran dan gerakan HTI di tingkat mahasiswa. Sebagaimana HTI yang mengusung tentang ide mengenai khilafah Islamiyah, maka gagasan yang dilontarkan oleh GEMA Pembebasan pun seperti itu, menggulirkan pemikiran revivalis Islam politik yang mengkampanyekan penegakan khilafah dan penegakan syariat Islam secara kaffah. Selain memiliki sayap organisasi, yaitu GEMA Pembebasan juga memiliki perwakilan yang dinamakan chapter HTI atau semacam koordinator kampus di tingkat UWGM.

Fenomena yang berbeda akan kita dapati di HMI, di dalam organisasi HMI dinamika pemikiran dan organisasi keislaman lebih dinamis. Dalam arah gerakan organisasi, HMI sangat dinamis dengan ciri sebagai organisasi yang multikultur dan tentu saja multikepentingan. HMI sebagai organisasi kemahasiswaan sering kali memainkan ritme politik dan bahkan cukup memberikan pengaruh dalam skala politik, khususnya lokal Samarinda dan Kaltim.Dalam arah pemikiran pun demikian, HMI diwarnai oleh kader-kader yang memiliki kecenderungan afiliasi pemikiran bahkan ideologi yang berbeda, sehingga hal ini melahirkan dialektika pemikiran yang cenderung sangat dinamis. Kader-kader HMI lebih responsif dalam mengkaji dinamika pemikiran Islam dari berbagai perspektif, sehingga dalam tubuh HMI terjadi heterogenitas kader yang berbeda anutan pemahaman ataupun mazhab keislaman.

Dua organisasi kemahasiswaan yang merupakan sayap atau ortom dari ormas Islam terbesar di Indonesia, Pergerakan Mahasiswa Islam (PMII) yang merupakan organisasi sayap NU dan Ikatan mahasiswa Muhammadiyah yang merupakan organisasi otonom Muhammadiyah di tingkat mahasiswa tidak tampak di permukaan dalam kancah dinamika organisasi di UWGM. Keduanya tidak cukup dikenal di kalangan mahasiswa. Dari kedua organisasi tersebut hanya PMII yang memiliki komisariat di UWGM, meski pada kenyataannya komisariat PMII tersebut tidak terlihat keaktifannya.

Selain organisasi yang bersifat formal, di UWGM juga terdapat organisasi atau kelompok mahasiswa yang bersifat kultural atau semacam study club. Kelompok tersebut biasanya concern pada pengkajian atau gerakan yang berfokus pada satu tema saja. Misalnya Jaringan Aktivis Filsafat Islam (JAKFI) yang terfokus pada kajian atau diskusi-diskusi pemikiran dan filsafat Islam terdapat pula kelompok mahasiswa yang menamakan dirinya kelompok GEMILANG yang secara umum berhaluan pada pemikiran Syiah. Dinamika organisasi di UWGM, selain organisasi eksternal terdapat pula organisasi internal, untuk yang berbasis keislaman bernama Lembaga Dakwah Kampus Centra Studi Islam Mahasiswa (LDK CESIMA)

Aktivitas organisasi Islam di kampus UWGM adalah dengan melakukan kegiatan kaderisasi yang merupakan program yang bersifat rutin, diskusi berkala dan tematik, hingga kegiatan besar seperti seminar dan lainnya yang berhubungan dengan tema-tema keislaman, tema-tema politik nasional maupun tentang kondisi update kondisi dunia internasional. Organisasi Islam di kampus melaksanakan kegiatannya umumnya dilaksanakan di dalam kampus, namun terkadang juga melakukan kegiatan di luar kampus. Kegiatan dilaksanakan baik secara mandiri maupun dengan melakukan kerjasama dengan organisasi maupun lembaga yang lain, baik lembaga kemahasiswaan maupun bukan.

Aktivitas di mesjid kampus dikelola oleh pengurus LDK CESIMA, bahkan organisasi tersebut. Kegiatan di mesjid kampus biasanya marak dengan forum diskusi terbatas atau yang disebut liqo berupa kajian atau diskusi terbatas yang terdiri atas 1 orang mentor dan jumlah peserta terbatas, yaitu 4 atau 5 orang. Kerap juga dilaksanakan kegiatan diskusi terbuka dalam rangka even atau momentum tertentu yang dihadiri oleh puluhan bahkan hingga ratusan orang dengan mengundang pemateri dari luar. Pemateri atau ustadz yang diundang biasanya berasal dari alumni CESIMA Unmul.

\section{Peta Paham Keagamaan Mahasiswa yang Berkembang}

Sebelumreformasiterpetakanantarakelompok muslim yang mainstreem dalam hal ini HMI dan kelompok revivalis yang merupakan perwujudan dari gerakan tarbiyah Ikhwanul Muslimin yang bercokol di Lembaga Dakwah Kampus CESIMA. Pasca reformasi kelompok revivalis semakin menguat, dengan masuknya KAMMI kemudian GEMA. HMI masih tetap eksis sebagai antitesa dari kelompok tarbiyah yang bercokol di lembaga intra kampus. HMI paham keagamaannya cenderung pada paham keagamaan Islam modernis yang sangat dipengaruhi oleh pemikiran Nurcholish Madjid 
selaku penyusun dokumen Nilai Dasar Perjuangan (NDP) HMI. Paham keagamaan di HMI cenderung plural, karena varian wacana keislaman yang dikaji oleh kader-kader HMI memang beragam. PMII memiliki kecenderungan paham keagamaan tradisional yang sangat dipengaruhi oleh pemikiran Gus Dur, sedangkan IMM cenderung pada pemikiran keagamaan modernis.

Dari segi bacaan, anak-anak HMI cenderung pada bacaan Islam yang lebih intelektual dan filosofis, seperti buku Murtadha Muthahhari, Ali Syariati, pemikir Indonesia seperti Nurcholis Madjid, Dawam Rahardjo, dan lain-lain. Kader anak KAMMI dan CESIMA lebih cenderung pada bacaan dari pemikiran kelompok Ikhwanul Muslimin, seprti Hassan al-Banna, Sayyid Qutd, Abdul Qadir Audah, Said Hawwa, atau pemikir Islam modernis atau revivalis Indonesia, seperti Buya Hamka, Natsir, maupun buku-buku yang ditulis oleh aktivis ikhwanul muslimin dalam hal ini PKS. Kader-kader GEMA (Gerakan Mahasiswa) Pembebasan dan HTI kecenderungan bacaannya pada pemikiran politik Taqiyuddin an-Nabhani atau kelompok Hizbut Tahrir. Kader PMII lebih cenderung pada bacaan pemikiran Islam tradiosionalis atau posttradisionalis, misalnya karya-karya pemikir Islam seperti Abed al-Jabiri, Mohammed Arkoun, Gus Dur, Ahmad Baso, atau pemikir Islam kritis lainnya.

Mahasiswa lebih cenderung pada organsiasi keislaman yang berpahaam mdoerat dalam hal ini diwakili oleh HMI dan kelompok-kelompok studi yang membahas Islam secara lebih moderat dan intelektual,misalnya Jaringan Aktivis Filsafat Islam (JAKFI), kelompok studi Gemilang, dan lain-lain. Namun, tak sedikit pula kecenderungan mahasiswa untuk aktif pada organisasi keislaman yang mengusung isu-isu radikal dan berorientasi pada spirit politik Islam, seperti KAMMI, GEMA, maupun LDK CESIMA.

Aktivis organiisasi CESIMA, KAMMI, maupun GEMA Pembebasan yang notabene dicap sebagai kelompok "radikal", puritanis, maupun revivalis, cenderung mempraktekkan keagamaan secara sangat normatif dan taat. Mereka selalu mengisi egiatan shalat wajib di mesjid kampus. Pada praktek keberagamaan kelompok ini terkesan eksklusif. Kelompok moderat dalam hal ini HMI corak keberagamaannya meski terkesan moderat namun pada aspek normatif tampak kurang taat atau tidak setaat anak-anak CESIMA. Pada praktek keberagamaannya anak-anak HMI lebih inklusif. Kalangan aktivis KAMMI, Gema, dan CESIMA, menjadikan isu-isu dunia Islam internasional sebagai ekcenderungan mereka. Terkhusus kelompok Gema menjadikan isu khilafah sebagai isu senral kelompok mereka. Sedangkan KAMMI dan CESIMA lebih fokus pada isu-isu keagamaan ang bertemakan akidah atau pengamalan syariat, serta isu-isu tentang kesesatan kelompok Syiah. Untuk aktivis HMI isu keagamaan yang digandrungi adalah isu tentang rekonstruksi pemahaman keagamaan dengan pendekatan kritis dan filosofis, sehingga kader-kader HMI tak sedikit yang akhirnya cenderung pada pemikiran Syiah bahkan hingga mempraktekkan tata cara keberislaman berdasarkan fikih Syiah.

Isu kebangsaan yang diangkat oleh seluruh gerakan mahasiswa Islam adalah isu tentang politik kebangsaan, kebijakan pemerintah, dll. Namun, diantara mereka terjadi perbedaan pandangan dan penyikapan terhadap isu kebangsaan tersebut. Cara pandang aktivis HMI lebih cenderung pada konsep kebangsaan yang dimana hukum dan undangundang tidak ditegakkan secara konsekuen, supremasi hukum masih belum ditegakkan. Sedangkan anak KAMMI dan GEMA lebih menyoroti karena Islam tidak diposisikan sebagai dasar negara yang menjadi penyebab persoalan kebangsaan.

Isu bentuk negara oleh kalangan aktivis KAMMI dan CESIMA lebih berorientasi pada konsep negara Islam atau daulah, meski mereka tidak menunjukkan greget yang besar untuk memperjuangkan hal tersebut. Sedangkan kalangan Gema isu kebangsaannya adalah isu tentang khilafah Islamiyah. Sedangkan aktivis HMI lebih cenderung pada bentuk negara NKRi dengan pancasila sebagai dasar negara. Perspektif tentang tradisi lokal tidak menjadi isu yang hangat kecuali bagi kalangan KAMMI dan CESIMA yang kurang care terhadap tradisi lokal keislaman. HMI cenderung berpemahaman moderat Islam dan sebagian aktvisnya mengusung pemikiran Islam yang rasional dan filosofis. Sedangkan KAMMI dan CESIMA lebih cenderung pada pemahaman keagamaan yang modernis-revivalis, demikian pula GEMA, namun diantara keduanya memiliki perbedaan dalam konsep strategis dan metodologis dalam memperjuangkan Islam. CESIMA berhaluan Ikhwanul Muslimin dan mengikuti pemikiran 
Hasan al-Banna, Sayyid Quthb, atau Abdul Kadir Audah, sedangkan GEMA berafiliasi pada kelompok Hizbut Tahrir dan mengikuti pemikiran politik Islam Syeikh Taqiyuddin an-Nabhani.

\section{Pergeseran Paham Keagamaan di Kalangan Mahasiswa Islam Sejarah dan Perkembangan Paham Keagamaan Baru}

Kelompok yang dapat dianggap sebagai kelompok yang mengusung pemahaman keagamaan baru yang menggeser paham keagamaan Islam mainstreem di kalangan mahasiswa adalah kelompok KAMMI (Kesatuan Aksi Mahasiswa Muslim Indonesia) yang berafiliasi kepada ikhwanul muslimin dan secara politik segaris dengan PKS (Partai Keadilan Sejahtera) dilatarbelakangi oleh sosialisasi yang dilakukan oleh aktivis KAMMI Kaltim ke kampus UWGM kemudian direspon oleh beberapa mahasiswa dan akhirnya membentuk komisariat di kampus UWGM. CESIMA sebagai organisasi intra kampus dilatarbelakangi oleh pengajian rutin yang dilakukan oleh mahasiswa antar fakultas, kemudian pada bulan juni tahun 2000 disepakati untuk didirikanlah CESIMA sebagai lembaga dakwah kampus (LDK), secara pemikiran LDK CESIMA sehaluan dengan KAMMI. Kelompok yang treakhir adalah Gema Pembebasan yang berafiliasi pada organisasi Hizbut Tahrir Indonesia yang mengusung isu khilafah Islamiyan. Latar belakang kelompok tersebut hadir di UWGM adalah adanya beberapa mahasiswa UWGM yang aktif mengikuti kegiatan halaqah yang dilakukan oleh HTI, hingga akhirnya membentuk organsiasi Gema Pembebasan sebagai sayap organisasi HTI di kampus.

Latar belakang munculnya paham tersebut didasarkan pada kecenderungan mahasiswa yang memiliki minat belajar agama, dan kecenderungan ini disambut oleh kelompok-kelompok tersebut untuk memberikan pengajaran dasar agama Islam, berupa baca tulis Alquran, tata cara shalat, dan materi-materi lain seputar dasar keislaman

Karena kelompok tersebut cukup intensif memberikan pembinaan dasar-dasar agama Islam yang mereka masih kurang dalam pengetahuan maupun pengamalan. Pendekatan persuasif dan emosional juga cukup memberikan pengaruh kepada mahasiswa hingga akhirnya tertarik untuk bergabung. Deskripsi tentang realitas umat Islam baik di Indonesia maupun dalam dunia internasional juga menjadi pemantik gairah mahasiswa untuk tertarik dan akhirnya bergabung serta terlibat aktif di dalamnya.

Paham keagamaan dikembangkan melalui kegiatan-kegiatan seperti mentoring agama Islam yang sifatnya terbatas, pengajian atau ta'lim yang dilakukan sekali sepekan, yaitu setiap sabtu sore atau sabtu malam, kegiatan Islamic Leadership training yang merupakan pola rekrutmen kader secara resmi. Seminar-seminar dengan mengambil tema isu-isu keislaman dan politik dunia Islam serta peringatan hari besar agama Islam seperti maulid, isra miraj, dll dijadikan medium pengembangan paham keagamaan mereka. Kerjasama dengan LDK lain maupun organisasi keagamaan yang sehaluan juga dijadikan sebagai medium untuk memeprluas pengembangan paham keagamaan mereka.

Landskap keagamaan di kampus UWGM sebelum kelompok ini berkembang adalah kehidupan keagamaan yang biasa-biasa saja, bahkan cenderung kurang dari nuansa keislaman, di mana banyak mahasiswa muslim yang belum dapat membaca Alquran maupun tidak tahu bagaimana tatacara melaksanakan shalat, landskap inilah yang menjadi latarbelakang kehadiran kelompok keagamaan baru tersebut. Kondisi pemikiran dan gerakan pada saat kelompok ini masuk di kampus UWGM adalah Pemikiran dan gerakan keagamaan didominasi oleh HMI sebagai satusatunya organisasi mahasiswa Islam yang eksis dan berekmbang di kampus. Pemikrian dan gerakan HMI cenderung bercorak gerakan politis, sehingga tidak terlalu mewarnai pemikrian dan gerakan keagamaan di kampus.

Ketertarikan mahasiswa pada LDK CESIMA menurut seorang anggota LDK CESIMA, pertama kali dia berkenalan dengan kelompok LDK adalah ketika ia mahasiswa baru diperkenalkan dengan adanya LDK CESIMA sebagai tempat belajar agama Islam secara intensif. Pendekatan intensif dan emosional yang dilakukan oleh senior-senior CESIMA. Ia yang juga belum bisa membaca Alquran juga diajari secara intensif bagaimana membaca Alquran serta praktek ibadah. Karena hal tersebutlah ia kemudian tertarik untuk bergabung dan akhirnya aktif dalam setiap kegiatan CESIMA.

\section{Profil Gerakan Keagamaan Baru}

Secara eksternal adalah KAMMI dan Gema Pembebasan. KAMMI berafiliasi pada kelompok 
ikhwanul muslimin dan memiliki jaringan dengan PKS. Sedangkan Gema Pembebasan berafiliasi pada kelompok Hizbut tahrir Indonesia. Struktur organisasi KAMMI dan Gema Pembebasan adalah komisariat Universitas Widyagama Mahakam, yang merupakan struktur dari KAMMI daerah Kaltim dan Gema Pembebasan Cabang Samarinda.

Di internal kampus gerakan keagamaan baru diusung oleh organisasi Lembaga Dakwah Kampus (LDK) CESIMA (Centra Studi Islam Mahasiswa) yang berafiliasi dengan kelompok Ikhwanul muslimin dan memiliki jaringan koordinasi dan kerjasama dengan LDK lain yang sehaluan, dalam hal ini Pusdima (Pusat Studi Islam Mahasiswa) Universitas Mulawarman. Kelompok yang dominan adalah CESIMA, karena merupakan organisasi resmi internal kampus yang berbentuk UKM (Unit Kegiatan Mahasiswa). Pada penelitian ini fokus diarahkan kepada kelompok CESIMA, selaku kelompok yang dominan dalam mengusung arus baru pemikiran dan gerakan Islam di kampus Universitas Widyagama Mahakam Samarinda.

Profil keagamaan baru yang menjadi sorotan dalam penelitian ini adalah kelompok LDK CESIMA. Hal ini didasarkan pada pertimbangan bahwa kelompok tersebut adalah kelompok keagamaan muslim yang cukup dominan dan menjadi organisasi resmi di kampus serta memiliki saluran resmi karena dipercayai mengelola mesjid kampus UWGM. Adapun kelompok lain seperti Hizbut tahrir tidak menjadi sorotan, karena kelompok tersebut gerakannya tidaklah semassif CESIMA.

CESIMA didirikan pada bulan September tahun 2000 dengan tujuan sebagai centra pembinaaa keagamaan mahasiswa UWGM. Pendirian CESIMA diinspirasi dari keberadaan LDK PUSDIMA Universiats Mulawarman dan pada awalnya LDK PSUDIMA menajdi pembina dalam kegiatan pembinaan keislaman yang dilakukan oleh CESIMA. Di kampus UWGM, LDK CESIMA mendapatkan sekertariat di mesjid kampus dan dipercayakan mengelola mesjid kampus UWGM. Saat ini untuk organisasi CESIMA struktur organisasinya terdiri atas ketua umum, sekum, bendahara umum, dan beberapa bidang (bidang syiar dan kader, pengembangan SDM, keuangan, Humas, media, dan jaringan). Ketua umum saat ini adalah Panji Nur Prasetyo, mahasiswa Fakultas Kesehatan Masyarakat angkatan 2012.

\section{Pola Rekruitmen Kader}

Rekruitmen anggota dilakukan pertama kali melalui sosialisasi ketika penerimaan mahasiswa baru, kemudian dilakukan mentoring yang dikoordinir oleh seorang mentor (murabbi') kepada beberapa orang mahasiswa baru biasanya 4-7 orang, kelompok mentoring ini intensif melakukan kajiankajian seputar tema keislaman, baca tulis Alquran, hingga praktek ibadah, dan materi-materi Islam yang bercorak ideologis. Selain itu ada taklim pekanan taman yang merupakan pengajian rutin mingguan yang dilakukan setiap sabtu bertempat di mushalla kampus UWGM. Setelah beberapa bulan berjalan, kemudian diadakan Leadership Training sebagai ajang rekrutmen anggota baru, anggota yang ikut adalah mereka yang intensif mengikuti mentoring dan taklim pekanan. CESIMA juga mendapatkan kewenangan untuk membantu tugas dosen agama Islam dalam hal pembinaan dan praktikum ibadah mata kuliah agama Islam. Mentor diberikan kewenangan untuk memberi nilai dan nilai tersebut nantinya akan menjadi masukan bagi dosen agama dalam memebrikan nilai bagi mata kuliah Pendidikan Agama Islam.

Proses pengkaderan yang dilakuan adalah melalui mentoring dan taklim. Kemudian dilakukan pengakderan resmi, yaitu leadership training sebagai ajang rekrutmen resmi anggota baru. Sosialisasi diawal penerimaan mahasiswa baru, mentoring, taklim mingguan, seminar keislaman, peringatan hari besar Islam, hingga diskusi-diskusi terbatas maupun terbuka, dan kegiatan leadership training yang dilakukan 1 atau 2 kali dalam setahun, tergantung kondisi. Materi-materi yang diberikan adalah pembinaan baca tulis Alquran, praktikum ibadah, materi seputar akidah Islam, fikih, akhlak, hingga tema-tema umum seperti realiats dunia Islam, perkembangan dunia Islam, tema-tema politik Islam, serta aliran-aliran dalam Islam. Pemateri berasal dari senior-senior CESIMA, dosen agama Islam UWGM, kerap juga pemateri dari Pusdima Unmul, maupun ustadz-ustadz lainnya yang berasal dari kelompok tarbiyah ikhwanul muslimin atau PKS dan kelompok yang sehaluan.

\section{Perspektif Keagamaan dan Sikap terhadap Kelompok Lain serta Tradisi Lokal}

Agama Islam dipahami sebagai ajaran yang lengkap dan berisi panduan bagi seluruh sendi kehidupan manusia. Islam merupakan ideologi 
yang tidak hanya mengatur soal-soal peribadatan semata, namun juga mengatur aspek-aspek sosial termasuk yang berkenaan dengan konsep negara. Manhaj keislaman kelompok ini adalah manhaj ahlussunnah wal jamaah yang didasarkan pada cara pandang Islam sebagai mabda' pandangan hidup atau ideologi dan Islam sebagai haraki atau gerakan. Islam harus ditegakkan secara kaffah (totalitas) dalam seluruh sendi kehidupan manusia baik dalam kehidupan pribadi maupun kehidupan sosial.

Dalam menafsirkan Alquran dipahami oleh kelompok ini bahwa Alquran harus ditafsirkan sesuai dengan kaidah-kaidah tafsir yang telah ditetapkan oleh para mufassir awal, penafsiran terhadap Alquran tidak boleh memasukkan metode barat dalam hal ini filsafat atau hermeneutika. Menafsirkan Alquran harus kembali kepada penafsiran para ulama yang kompeten. Ajaran ulama diposisikan sebagai sumber rujukan untuk memahami Islam selama pendapat ulama tersebut tidak bertentangan dengan Alquran dan hadis sebagai rujukan utama. Hanya pendapat ulama yang jelas-jelas terbukti sesuai dengan Alquran dan hadis saja yang diambil. Tidak boleh ada fanatisme terhadap ulama atau mazhab tertentu, dengan demikian mereka menolak bermazhab alias bebas mazhab. Mendasarkan pemahaman dan pengamalan keislaman pada doktrin pokok Alquran dan hadis shahih adalah yang pokok.

Dalam memahami dasar-dasar ajaran Islam menurut mereka, yaitu pemahaman, penghayatan, dan pengamalan rukun Islam dan rukun iman. Rukun iman dan rukun Islam adalah doktrin pokok agama Islam yang barangsiapa tidak memeprcayai salah satunya maka keislamannya gugur, termasuk diantaranya menambahi pokok-pokok rukun iman tersebut berarti telah menambah-nambah ajaran agama Islam dari nabi. Seperti kelompok Syiah yang menambah keyakinan terhadapimamah dalam rukun iman mereka dan Ahmadiyah yang mempercayai adanya nabi setelah Nabi Muhamamd saw. Dengan demikian, kedua kelompok tersebut telah keluar dari pokok ajaran Islam yang sebenarnya.

Berkenaan dengan perspektif mengenai ritual keagamaan dalam Islam, menurut pandangan mereka harus sesuai dengan dalil naqli yang qath'i (jelas) yakni Alquran dan ahdis shahih. Peribadatan yang tidak bersandar pada dalil qath'i yaitu Alquran dan hadis shahih adalah amalan bid'ah yang harus dihindari. Konsep lain yang mereka anggap penting dalam memahami doktrin Islam adalah konsep tentang jihad. Jihad adalah kewajiban bagi setiap muslim, meski jihad yang dipahami tidak dilaksanakan dengan kekerasan. Jihad tidak melulu dengan menggunakan pedang, melainkan jihad yang saat ini kontekstual adalah dengan menggunakan pena atau ilmu pengetahuan. Memanfaatkan media informasi dan teknologi merupakan bagian dari jihad atau perjuangan untuk menyebarkan agama Islam yang sebenarnya. Jihad yang diusung oleh ISIS, al-Qaeda, kelompok Mujahidin adalah jihad yang tdak konteks dan cenderung mencederai citra umat Islam. Oleh karena itu, mereka tidak sepakat dengan konsep jihad yang diusung oleh kelompokkelompok tersebut.

Perspektif tentang konsep pluralisme, secara tegas mereka menolak pluralisme agama, karena hal tersebut bertentangan dengan ajaran Islam. Menurut mereka, kita mesti menerima plurlitas namun menolak paham pluralisme agama, karena paham tersebut adalah paham yang bertentangan dengan ajaran Islam karena menyamakan kebenaran semua agama. Agama Islam adalah ya'lu wala yu'la alaih artinya agama Islam adalah agama yang paling agung dan tidak ada agama lain yang menandingi. Agama Islam adalah satu-satunya agama yang benar dan diterima oleh Allah, percaya pada kebenaran dan keselamatan pada ajaran agama lain adalah bertentanga dengan ajaran Islam. Kawin beda agama adalah hukumnya haram dengan alasan apapun. Bertetangga dengan beda agama bolehboleh saja selama mereka tidak mempengaruhi atau menghormati keyakinan umat Islam. Memberi ruang beribadah kepada agama lain juga boleh-boleh saja, selama mereka tidak mengganggu ketentraman umat Islam dan tidak menyebarkan agamanya kepada umat Islam. Penghormatan kepada agama lain tidak meniscayakan kita ikut serta dalam acara, tradisi, atau pun ritual mereka, termasuk diantaranya ikut serta mengucapkan selamat natal kepada umat Kristiani yang merayakannya.

Dalam memposisikan ajaran ulama mereka berpandangan Ajaran ulama diposisikan sebagai sumber rujukan untuk memahami Islam selama pendapat ulama tersebut tidak bertentangan dengan Alquran dan hadis sebagai rujukan utama. Hanya pendapat ulama yang jelas-jelas terbukti sesuai dengan Alquran dan hadis saja yang diambil. Tidak boleh ada fanatisme terhadap ulama atau mazhab tertentu, dengan demikian mereka menolak 
bermazhab alias bebas mazhab. Mendasarkan pemahaman dan pengamalan keislaman pada doktrin pokok Alquran dan hadis shahih adalah yang pokok.

Terhadap kelompok yang beda agama, Islam mengajarkan lakum dinukum waliyadin. Islam mengajarkan toleransi dalam beragama namun bukan berarti toleransi tersebut disalahgunakan dan dimaknai untuk ikut serta dalam praktek keagamaan mereka, seperti mengucapkan selamat pada hari raya mereka, dll. Islam menghormati perbedaan agama, selama umat agama lain juga menghormati umat Islam, tidak menganggu, serta tidak menyebarkan agama mereka kepada umat Islam. Kepada kelompok yang beda paham dalam Islam, selama perbedaan tersebut hanya berkenaan dengan hal-hal yang bersifat furu' atau cabang, maka harus ada toleransi dan saling menghormati satu sama lain. Namun, jika perbedaan menyangkut hal yang bersifat prinsipil dalam agama, maka tidak ada toleransi dan harus dilakukan upaya untuk menerangkan kepada masyarakat akan bahayanya kelompok tersebut. Contoh kelompok tersebut adalah Syiah dan Ahmadiyah.

Kepada kelompok yang tidak sehaluan harus ada sikap saling menghormati, karena sebenarnya tujuan universalnya adalah sama namun terdapat perbedaan dalam cara pandang dan metodologi dalam memperjuangkan Islam. Sebagai sebuah gerakan keislaman, maka CESIMA memiliki komitmen pada manhaj yang digariskan oleh gerakan ikhwanul muslimin, maka kepada kelompok yang lain yang sama-sama memperjuangkan Islam namun tidak sehaluan dengan CESIMA, CESIMA tetap menghormati perbedaan namun tidak memperkenankan kelompok tersebut masuk dan membawa pengaruh pada CESIMA yang dapat mengubah haluan dan pilihan manhaj keislaman CESIMA.

Kelompok minoritas dalam Islam seperti Syiah dan Ahmadiyah merupakan kelomppok yang telah menyimpang dari ajaran Islam yang sebenarnya. Oleh karena itu, CESIMA memiliki komitmen untuk menyadarkan kelompok-kelompok tersebut dan membentengi masyarakat dari pengaruh kelompok tersebut. Kegiatan yang dilakukan dalam rangka hal tersebut adalah dengan melakukan kajian ilmiah tentang Syiah, seminar terbuka, dan pembagian selebaran yang berisikan ifnormasi tentang ajaran Syiah yang sedang berkembang dan harus diwaspadai.
Lelaku tasawuf atau sufi sebagaimana yang selama ini dipahami tidak memiliki dasar dalam ajaran Islam. Bahkan pelaku tasawuf sangat rentan mengarah pada penyimpangan dari ajaran agama Islam yang sesungguhnya. Tradisi keislaman yang lazim di Indonesia adalah tradisi yang dipengaruhi oleh kepercayaan nusantara pra Islam, sehingga tradisi tersebut tidak memiliki dasar bahkan bertentangan dengan ajaran Islam. Praktek-praktek tradisi Islam nusantara sangat rentan dengan praktek keagamaan yang tidak memiliki contoh dari Nabi maupun salafus saleh atau bid'ah. Pada beberapa praktek tradisi kerap bernuansa musyrik. Dengan demikian penerapan Islam yang sesungguhnya haruslah membersihkan pemahaman dan pengamalan masyarakat dari segala pengaruh dari unsur luar Islam. Karena ada hadis dari Rasulullah saw barangsiapa menyerupai suatu kaum, maka ia akan termasuk dari kaum tersebut.

Adapun tentang praktek Islam lokal adalah Islam yang bersifat sinkretik dan masih meyakini hal-hal yang berbau anismisme dan dinamisme. Kelompok Islam lokal adalah kelompok yang mencampurbauran antara agama Islam dengan tradisi di luar Islam. Untuk menyikapi kelompok Islam lokal tidak boleh dengan cara frontal, melainkan harus perlahan dan bijaksana dengan memberikan penjelasan kepada masyarakat bahwa apa yang mereka lakukan itu tidak sesuai dengan ajaran Islam yang sesungguhnya dan bahkan bertentangan dengan keyakinan Islam, karena pada beberapa praktek tradisi berbau musyrik atau menduakan Allah.

Kepada keluarga yang tidak sehaluan diberikan pemahaman sedikit demi sedikit dengan melakukan pendekatan yang bersifat persuasif dan intensif. Namun jika mereka tetap pada pandangannya maka tak jemu untuk terus menerus memberikan pemahaman tentang Islam yang sesungguhnya. Perbedaan di tengah keluarga disikapi dengan arif dan tidak frontal, namun juga tidak berarti harus bersikap kompromistis. Dakwah kepada keluarga harus terus dilakukan meskipun mereka melakukan penentangan kepada pemahaman Islam yang didakwahkan kepada mereka. Semangat tak mengenal lelah untuk berdakwah kepada keluarga adalah motivasi yang membuat kader-kader CESIMA tak pernah jemu menjelaskan pemahaman keislamannya kepada keluarga mereka. 


\section{Paham Politik dan Kebangsaan}

Dalam pandangan CESIMA mengenai Bentuk negara Indonesia saat ini bukanlah merupakan bentuk negara yang ideal, karena seharusnya bentuk negara ideal itu adalah bentuk negara Islam. Dengan demikian, bentuk negara NKRI agar menjadi ideal harus didasarkan pada Islam sebagai dasar negara. Meski mengidealkan bentuk negara Islam, namun dalam perjuangan untuk memperjuangkan bentuk negara Islam adalah dengan perjuangan yang elegan melalui jalur politik dengan berusaha masuk dan berjuang melalui parlemen. Itu sebabnya mereka menjadikan PKS sebagai wadah aspirasid an perjuangan politik. NKRI adalah bentuk yang ideal bagi Indonesia, hanya saja harus berdasarkan pada Islam sebagai dasar negara.

Dalam memahami bhineka tunggal ika adalah realitas bangsa yang harus diterima sebagai anugerah dan khasanah. Namun, kebhinekaan bukan berarti meleburkan dan mengaburkan identiats Islam. Islam sebagai agama mayoritas adalah yang paling berhak untuk menentukan arah dan dasar negara. Nasionalisme atau paham cinta tanah air adalah penting selama tidak berlebih-lebihan dan mengalahkan kecintaan kepada Islam. Oleh karena itu, nasionalisme harus dilandasi bukan hanya pada spirit kebangsaan tapi juga spirit keislaman sebagai dasar dari nasionalisme.

Mengenai konsep negara Islam mereka berpandangan bahwa negara Islam adalah bentuk negara yang ideal dalam bentuk sistem teodemokrasi yang didasarkan pada nilai dan penerapan hukum Islam. Bentuk negara Islam bukan berarti menegasi kejamakan. Justru dengan bentuk negara Islam kelompok minoritas penganut agama lain akan diberikan hak-haknya sebagai warga negara secara adil dalam naungan pemerintah Islam. Konsep khilafah sebagaimana yang diusung oleh Hizbut Tahrir seara prinsipil adalah sehaluan dengan cara pandang CESIMA, hanya saja perbedaan mendasar pada model dan metodologi perjuangan yang berbeda secara mendasar. Bagi CESIMA, sebagaimana kelompok Ikhwanul muslimin, daulah atau khilafah Islam harus diperjuangkan melalui cara-cara yang konstitusional. Demokrasi dapat dijadikan sarana untuk perjuangan, sedangkan kelompok Hizbut Tahrir menganggap demokrasi adalah sistem kufur. Perbedaan-perbedaan inilah yang membuat antara kedua kelompok tersebut tidak bisa sejalan dalam gerakannya.
Formalisasi Islam melalui perda syariat adalah suatu hal yang positif guna membumikan ajaran Islam di tengah masyarakat. Dengan formalisasi syariat Islam melalui perda akan membiasakan masyarakat untuk taat kepada syariat Islam, seperti baca tulis Alquran, pebayaran zakat, dan lain-lain. Perda syariat menjadi langkah untuk memperkenalkan penerapan syariat Islam secara lebih luas kepada masyarakat. Riil pancasila adalah piagam Jakarta yang memuat 7 kata, yaitu "dengan kewajiban menjalankan syariat Islam bagi pemelukpemeluknya". Naskah piagam Jakarta merupakan nilai pancasila yang sejati karena mengakomodir kebhinekaan sekaligus megakomodir aspirasi umat Islam dalam hal penerapan syariat Islam bagi umat Islam. Perjuangan yang harus dilakukan adalah dengan menerapkan kembali pancasila versi piagam Jakarta.

Umat Islam merupakan kelompok bangsa yang paling punya kontribusi dalam membangkitkan kesadaran perjuangan untuk merebut kemerdekaan. Tokoh-tokoh Islam memiliki peran yang vital dalam sejarah berdirinya bangsa, hanya saja peran dan kontribusi ebsar umat Islam tersebut, tercederai dengan terhapusnya 7 kata dari piagam Jakarta.

Dalam menyikapi berlakunya hukum positif yang diterapkan di negeri ini menurut aktivis CESIMA bahwa hukum belum benarbenar mencerminkan keadilan sebagaimana yang ditujukan dari sebuah penegakan hukum. Supremasi hukum masih sangat lemah, sehingga hukum tidak benar-benar efektif dalam meberikan keadilan bagi amsyarakat. Ibarat pisau, hukum yang diterapkan tajam ke atas dan tumpul ke bawah. Produk hukum positif Indonesia hari ini masih didominasi oleh produk hukum warisan kolonial. Oleh karena itu, perlu direvisi dengan produk hukum yang benarbenar mumpuni dalam hal ini adalah hukum yang berasal dari ajaran Islam.

Demikian pula ketika dimintai tanggapan mengenai sistem ekonomi yang saat ini berlaku di Indonesia. Sistem ekonomi Indonesia masih mengarah pada sistem ekonomi kapitalis-liberalis. Hingga keadilan ekonomi tidak dapat diterapkan secara merata bagi seluruh masyarakat. Secara ekonomi dengan menganut sistem kapitalis, Indonesia akhirnya tidak dapat keluar dari belitan gurita ekonomi negara kapitalis yang mencekik perekonomian Indonesia. Sistem ekonomi ini juga membuat Indonesia tidak mampu mandiri secara 
ekonomi. Oleh karena itu, butuh sistem ekonomi yang benar-benar mumpuni dan penerapannya dapat menjamin pemerataan keadilan bagi seluruh rakyat, dan sistem ekonomi Islam adalah solusinya.

\section{Jaringan Gerakan Keagamaan}

Sebagai sebuah lembaga, CESIMA memiliki jejaring kelembagaan yang pada Kelompok yang sehaluan dalam paham, visi, dan misi keislaman. Jaringan CESIMA mencakup jaringan luar kampus baik intra LDK maupun di luar jaringan LDK. Untuk sesama LDK, CESIMA berjejaring dalam FSLDK, Kampus Pelangi, KAMMI, PKS, dan kelompok dakwah lain yang memiliki haluan manhaj keislaman yang sama dengan LDK CESIMA.Jaringan di luar kampus khususnya sesama LDK adalah dengan keanggotaan Forum Silaturahmi Lembaga Dakwah Kampus (FSLDK) yang secara struktur memiliki kepengurusan mulai dari tingkat pusat hingga daerah. LDK CESIMA Universiats Widyagama Mahakam Samarinda tergabung dalam organisasi linats LDk tersebut, serta terlibat dalam Puskomda (Pusat Komunikasi Daerah). Dengan LDK lain yang berasal dari perguruan tinggi non UWGM, seperti STIMIK Wucida, Untag, Poltek, Poltekes, IKIP PGRI, dan LDK lain di Samarinda, CESIMA membentuk forum LDK yang bernama Kampus Pelangi. Keberadaan kampus pelangi merupakan koordiansi antar LDk dari kampus-kampus tersebut guna saling membantu dan memeriahkan kegiatan masing-masing. LDK CESIMA juga membangun jaringan dengan LDK CESIMA UWGM dalam hal kerjasama kegiatan dan pembinaan anggota.

Dengan organisasi eksternal, LDK CESIMA UWGM memilik jaringan dengan organisasi eksternal KAMMI, hampir setiap anggota CESIMA adalah kader dari KAMMI. Selain itu LDK CESIMA juga membangun jaringan dengan kelompok PKS dan menjadikan PKS sebagai wadah aspirasi dan perjuangan poltik. Dengan kelompok keislaman yang lain, LDK CESIMA hanya menjalin silaturahmi, khususnya menghadiri kegiatan-kegiatan mereka ketika LDK CESIMA diundang.

Jaringan yang dimiliki di luar kampus dimanfaatkan untuk menguatkan gerakan dan pembnaan yang dilakukan oleh LDK CESIMA. Karena potensi sumberdaya yang dimiliki oleh LDk CESIMA dalam hal pembinaan dan pemberian materi kepada anggota masih kurang, maka dengan mengandalkan jaringan di luar kampus untuk melakukan pembinaan dan pemberian materi pada kegiatan taklim maupun perkaderan. Pemateri atau ustadz dari CESIMA, Puskomda, Kampus Pelangi, maupun dari PKS kerap dipanggil untuk mengisi materi pada saat taklim pekanan maupun kegiatan perkaderan, serta kegiatan-kegiatan rutin pembinaan anggota lainnya.

Jaringan strategis dalam isu-isu tertentu memanfaatkan jaringan yang telah ada dalam merespon hal-hal penting berkenaan dengan kondisi kebangsaan, keumatan, dan dunia Islam. Tidak ada jaringan khusus yang bersifat transnasional, LDK CESIMA hanya berjejaring dengan kelompok yang sehaluan secara ideologis dalam hal ini dengan lembaga-lemabaga yang secara ideologis berafiliasi pada kelompok Ikhwanul Muslimin.

Hubungan dengan birokrasi kampus dibangun secara baik melalui pendekatan persuasif dan dengan melibatkan diri dalam kegiatan-kegiatan kampus, khususnya kegiatan-kegiatan yang berkenaan dengan peringatan hari besar Islam. Hubungan dengan birokrasi kampus juga dibangun dengan kelompok dosen MDUU Agama Islam. Dalam mata kuliah tersebut, LDK CESIMA dipercayakan untuk berpartisipasi dalam mata kuliah tersebut melalui kegiatan mentoringg dan pembinaan praktikum mata kuliah agama Islam.

Hubungan dengan aparatur negara senantiasa tetap baik dengan tetap mengedepankan normanorma dan nilai agama. Gerakan memperjuangkan Islam tidak harus bersikap berhadap-hadapan dengan aparatur negara dan pemerintah. Hubungan dengan organisasi lain lebih bersifat hubungan silaturahim sebagai sesama organsiasi Islam, kecuali dengan organisasi yang memamg memiliki garisperjuangan dan manhaj dakwah yang sehaluan dalam hal ini kelompok KAMMI atau organisasi yang berhaluan Ikhwanul Muslimin. Dengan parpol, LDK CESIMA membangun hubungan koordinatif dengan Partai Keadilan Sejahtera sebagai partai yang dianggap sebagai wadah aspirasi dan perjuangan dalam memperjuangkan nilai dan ajaran Islam. Dengan demikian dapat dipastikan bahwa kader dan alumni CESIMA secara politik aktif di PKS baik sebagai simpatisan biasa maupun sebagai kader dan pengurus aktif di PKS, atau setidaknya PKS menjadi saluran aspirasi politik kader CESIMA dalam memperjuangkan visi dan misi keislamannya secara politik.

Meski memiliki jejaring dengan kelompok Islam puritan atau revivalis, LDk CESIMA 
mengedepankan pengajaran Islam dengan cara yang damai dan menolak segala bentuk kekerasan. Itu sebabnya LDK CESIMA menentang keras konsep jihad dengan kekerasan yang dilakukan oleh sekelompok umat Islam. Jihad yang sesungguhnya adalah perjuangkan menebarkan kesadaran akan pentingnya nilai dan penerapan Islam di tengah masyarakat melalui pendekatan pendidikan dan politik serta melalui model dakwah lain yang tentu saja lebih mengedepankan nilai-nilai kedamaian dan rahmat dari Islam.

\section{PENUTUP}

Dari data yang diperoleh, maka melalui penelitian ini dapat ditarik 3 kesimpulan untuk menjawab 3 permasalah penelitian tentang pergeseran paham keagamaan mahasiswa muslim di Universitas Widyagama Mahakam Samarinda Kalimantan Timur:

Bentuk pergeseran paham yang terjadi di kalangan mahasiswa muslim di UWGM Samarinda adalah pergeseran paham keagamaan ke arah paham keagamaan yang revivalis-modernis. Kelompok yang mengalami pergeseran pemahaman keagamaan dan menjadi sorotan dalam penelitian ini adalah Lembaga Dakwah Kampus Centra Studi Islam mahasiswa (CESIMA). Arah pemahaman keagamaannya cenderung pada paham keagamaan yang diusung oleh kelompok Ikhwanul Muslimin, sebagai gerakan keagamaan Islam revivalis yang berasal dari Mesir.

Pergeseran pemahaman keagamaan tersebut disebabkan oleh kuatnya penetrasi kelompok tarbiyah Ikhwanul Muslimin hingga akhirnya berhasil menguasai Lembaga Dakwah Kampus dan menjadi satu-satunya paham keagamaan yang dianut oleh CESIMA. Mahasiswa muslim yang kemudian tertarik dan ikut bergabung disebabkan CESIMA memiliki saluran resmi dari kampus selain sebagai lembaga dakwah kampus yang berstatus Unit Kegiatan Mahasiswa (UKM), CESIMA juga mendapatkan kewenangan untuk melakukan pendampingan dalam hal pembinaan keagamaan dengan bekerjasama dengan dosen mata kuliah Pendidikan Agama Islam.

Dalam konteks kehidupan beragama dan berbangsa paham keagamaan yang diusung sangat resisten karena bersikap anti terhadap berbagai khasanah tradisi Islam lokal termasuk juga sikap yang cenderung intoleran terhadap kelompok
Islam yang tidak sehaluan dengan mereka. Dalam hal pandangan politik kebangsaan dapat dikatakan sebagai kelompok yang mengancam eksistensi Pancasila sebagai dasar negara karena mereka berhasrat untuk mengembalikan tujuh kata "dengan kewajiban menjalankan syariat Islam bagi pemelukpemeluknya" dalam sila Pancasila dan melakukan perjuangan untuk memformalisasikan syariat Islam sebagai hukum negara.

\section{UCAPAN TERIMA KASIH}

Terimakasih penulis haturkan kepada informan yang telah membantu peneliti ketika melakukan penelitian ini, khususnya Kepada Rektor Universitas Widyagama Mahakam Samarinda Kalimantan Timur, mahasiswa muslim di UWGM Samarinda, dan seluruh informan yang tidak dapat penulis sebutkan. Kepada Kepala Balai Penelitian dan Pengembangan Agama Makassar yang telah menugaskan penulis dalam melakukan penelitian ini. Untuk dewan redaksi terimakasih atas termuatnya tulisan ini pada edisi ini.

\section{DAFTAR PUSTAKA}

Barton, Greg. 1999. Gagasan Islam Liberal di Indonesia, Jakarta: Paramadina \& Pustaka Antara.

Baso. Ahmad. 2012. Militisi Islam: Kritik Nalar Politik Islam Sebagai Kritik Kebenaran. Makalah (belum diterbitkan).

Binder. 1988. Islamic Liberalism a critique.

El Fadl, Khaled Abou. 2005, The Great Theft, Wrestling Islam From the Extremist. San Fransisco: Harper San Fransisco.

Hasan, Rifat. 1993. Mempersoalkan Istilah Fundamentalisme Islam. Jurnal Ulum Quran. Edisi No.3. Volume IV.

Kurzman, Charles. 1998, Liberal Islam: Madison Avenue: Oxford University Press

Moloney, Gail and Ian Walker. 2007, Social Representation and Identity: Content, Process and Power. New York : Palgrave Macmilan.

Nata, Abudin. 2001. Peta Keragaman Pemikiran Islam di Indonesia. Jakarta: Rajawali Press.

Peneliti Litbang Agama. 2010. Laporan Penelitian: Paham Keagamaan Mahasiswa. Makassar. Litbang Agama Makassar.

Profil Kampus Universitas Widyagama Mahakam Samarinda Kalimantan Timur. 
Rumadi. 2009. "Pandemi Idiologi Puritanisme Agama" dalam Alamsyah M.Ja'far (ed), Agama dan Pergeseran Representasi: Konflik dan rekonsiliasi di Indonesia. Jakarta: Wahid Institute
Sivan, 1990. Radical Islam Moderat Theologi and Modern Polities. New Haven and London: Yale University.

Woodward, Kathryn. 1997, Identity and Difference. London: SAGE Publicatio 